\title{
Whey Based Beverage: Its Functionality, Formulations, Health Benefits and Applications
}

Chavan RS ${ }^{1 *}$, Shraddha $\mathbf{R C}^{2}$, Kumar $\mathrm{A}^{1}$ and Nalawade $\mathrm{T}^{1}$

${ }^{1}$ National Institute of Food Technology Entrepreneurship and Management, Kundli-131028, Haryana, India

${ }^{2}$ Department of Biotechnology, Junagadh Agricultural University, Junagadh, Gujarat, India

\begin{abstract}
Ready-to-drink beverages offer the advantages of convenience and portability to today's busy consumers. Carbonation category includes both refrigerated and shelf-stable beverages, demand is stronger for shelf-stable products which offer ease of distribution and storage. Whey proteins are often the preferred source for ready-to-drink protein beverages because of their excellent nutritional qualities, bland flavor, ease of digestibility, and unique functionality in beverage systems. Five general trends have influenced food and beverage innovations since 1985: convenience, pleasure, ethnic fusion, tradition and importantly, health and wellness. Sales of energy drinks and ready-to-drinks have grown to $\$ 23$ billion. Whey beverages are generally classified into four basic types: mixtures of whey (processed or unprocessed, including UF permeates) with fruit or (rarely) vegetable juices; dairy-type, 'thick' beverages (fermented or unfermented); thirst-quenching carbonated beverages (the 'Rivella-type'); and alcoholic beverages (beer, wine or liqueurs).
\end{abstract}

Keywords: Whey; Fruit beverage; Alcoholic beverage; Sport drink

\section{Introduction}

In 2008, total production of liquid cheese whey accounted to 187 million metric tons out of which 3.2 million metric tons (1.7\%) was utilized by different industries for manufacturing value added products like, whey powder, whey protein concentrates, whey isolates etc. With a $6.3 \%$ increase in 2009 and sales of $\$ 1.03$ million sales of energy drinks is growing than any other category of the beverages. In last six years about 4,100 food and beverage products containing whey protein were introduced in U.S. market [1] Whey proteins have unique nutritional and functional properties which can be explored to deliver high protein products to consumers. Dairy proteins are generally having a neutral - $\mathrm{pH}$, therefore they can be used in manufacturing of beverages which are having different nutritional and functional attributes

Development of RTD drinks relies on the fact that caseins are very heat stable at neutral $\mathrm{pH}$. Whey proteins are not as heat stable at neutral $\mathrm{pH}$, which is why caseins or milk proteins appear much higher on the typical ingredient legend. Whey protein as a ingredient is generally used in manufacturing of products like; sports drinks, beverages, smoothies, meal replacements etc. Whey proteins have a fresh, neutral taste which can be used to prepare beverages by utilizing different fruits and vegetables.

Whey proteins are present in small quantity but have a high protein efficiency ratio (3.6), net protein utilization (95), biological value (104) and as compared to all other protein sources available they are next to egg protein in terms of nutritive value. Whey proteins is a source of $\alpha$-lactalbumin, $\beta$-lactoglobulin, bovine serum albumin, caseinomacropeptides, immunoglobulins, lactoferrin, lysozyme which are often associated with health benefits, such as enhanced immunity, anticancer properties, ant adhesive effect against pathogenic properties, as well as antiviral, antimicrobial (iron binding properties) and antihypertensive properties.

A variety of whey based beverages consisting of plain, alcoholic, carbonated and fruit flavored have been successfully developed and marketed all over the world. Benefits of the whey proteins can easily be enhanced by the beverages manufactures into different products i.e. highly soluble in a $\mathrm{pH}$ range of 2 to 10 , produces stable and clear beverages even in the $\mathrm{pH}$ range of 3.0 to 3.2 , etc. Other than good hydration of the proteins prior to $\mathrm{pH}$ adjustment and heating, developers don't need to incorporate too many other processes or added ingredients at that low $\mathrm{pH}$. Importance of whey cheese proteins can be assessed by the fact that it is used as a source of ingredients is used in 1,763 products processed in the USA and in 6,453 products throughout the World in 2005 [2].

\section{Beverage Market}

In 2005, functional beverages market valued at US $\$ 25$ bn [3]. As per the Mintel Business market research report [4], the functional drinks and natural RTD beverages market has grown to $\$ 23 \mathrm{bn}$. Sales of functional beverages and energy drinks in 2009 were reported to be 9 billion and 1.03 million respectively. The sales of diet drinks, waters and fruit juices showed considerable growth. Global beverage market can be divided into four segments: hot drinks, milk based drinks, soft drinks and alcoholic drinks (Figure 1). First segment i.e Hot drinks can be further classified into tea, coffee and hot malt-based products; second segment of Milk based drinks consists segments like white drinking milk and flavored milk products. Third segment of soft drinks can be further categorized into subcategories which include bottled water; carbonated soft drinks; dilutables, also known as squash and including powders, cordials and syrups; $100 \%$ fruit juice, and nectars with 25-99\% juice content; still drinks, including ready-to-drink (RTD) teas, sports drinks and other noncarbonated products with less than $25 \%$ fruit juice). Alcoholic drinks which form the fourth segment is comprised of products like beer, wine, spirits, cider, sake and flavored alcoholic beverages (pre-mixed spirits) (Figure 1).

*Corresonding author: Chavan RS, National Institute of Food Technology Entrepreneurship and Management, Kundli-131028, Haryana, India, E-mail: rupeshchavan.niftem@gmail.com

Received July 09, 2015; Accepted July 20, 2015; Published July 27, 2015

Citation: Chavan RS, Shraddha RC, Kumar A, Nalawade T (2015) Whey Based Beverage: Its Functionality, Formulations, Health Benefits and Applications. J Food Process Technol 6: 495. doi:10.4172/2157-7110.1000495

Copyright: (c) 2015 Chavan RS, et al. This is an open-access article distributed under the terms of the Creative Commons Attribution License, which permits unrestricted use, distribution, and reproduction in any medium, provided the original author and source are credited. 


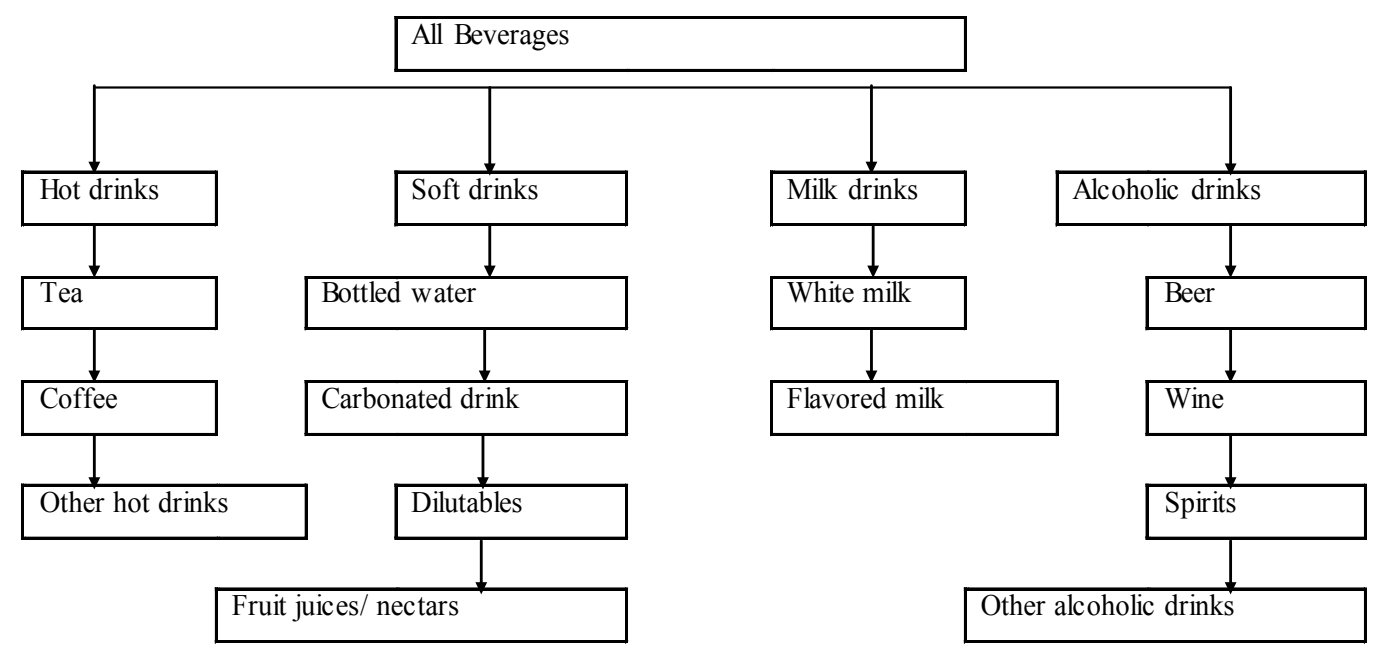

Figure 1: Beverage sectors and segments.

The total global beverages industry had a business of around $\$ 1,755.4$ billion in 2010, which depicted a CAGR of $2.3 \%$ for the period spanning 2007-2016. And the beverage industry is forecasted to accelerate, with an anticipated CAGR of $3.4 \%$ for the five-year period 2011-2016, which is expected to increase the value of the industry to about $\$ 2,072.9$ billion by the end of 2016. Consumers are now demanding for the products which are innovative in nature and with a enhanced functionality. Therefore products like flavoured waters, isotonics, yoghurt drinks, energy drinks, functional RTD teas and products similar to the segment will be shaping the future market of the beverage industry in comparison to the traditional products like $100 \%$ juice, colas, milk, teas and others.

\section{Need for Development of Whey Based Beverage}

Using cheese whey as a beverage in human nutrition, especially for therapeutic purposes, can be traced back to the ancient Greeks; Hippocrates, in 460 B.C. prescribed whey for an assortment of human ailments. The market dynamics is driven by five key factor groupings: increased concentration in the global beverages market; diverging functional beverage trends worldwide; flavor innovations; product differentiation; and cross-category innovations. Whey beverages are manufactured and formulated keeping in consideration the nutritional values, biological and functional properties.

The major problems which are generally encountered in whey based fruit juice beverages are:

a. Crystallization of lactose during storage at refrigerated temperature

b. Coagulation of whey proteins during thermal treatments

c. Higher viscosity of concentrates affect the effectiveness of thermal treatments

d. Depleted shelf-life at room temperatures

e. High content of minerals in the whey are responsible for undesired salty-sour flavour of whey.

Despite of the limitations of using whey in manufacturing beverages, whey is used on larger amounts due to the following reasons:

a. Whey is having a broad range of solubility i.e. from $\mathrm{pH}$ 3-8

b. Whey is having a bland flavor and on many occasion they can act as carrier for the aroma compounds. c. Buffering capacity of whey can be explored for survival of probiotic bacteria in the gastro intestinal tract.

d. Addition of whey improves the 'mouthfeel' of the drink by increasing the viscosity of the beverage.

e. Whey can be also used to solve the problems associated with cloudiness of tropical fruit juices and produce a cloud stable juice.

\section{Types of whey}

Whey proteins are available in different form viz., whey protein concentrates (WPC) and isolates (WPI), whey protein fractions ( $\alpha$-lactalbumin and $\beta$-lactoglobulin rich fractions, casein glycomacropeptide, lactoferrin, and lactoperoxidase) and protein hydrolysates (WPH) in the market (Table 1). Whey can be classified into two categories as per the production process as acidic whey $(\mathrm{pH}<$ 5), and sweet whey (pH 6 and $\mathrm{pH}$ 7) [5] (Table 1).

Adapted from reference manual for U.S. whey and lactose products [6].

WPC34: Whey Protein Concentrate 34\%; WPC80: Whey Protein Concentrate 80\%; WPC90: Whey Protein Concentrate 90\%; WPI: Whey Protein Isolate.

\section{Whey beverage types and their ingredients}

Given the advantages of whey protein, it has become a popular source of nutrition in a variety of forms: whey protein supplement bars, whey protein concentrates, whey protein isolates, and whey protein beverages. Four basic types of whey beverages were identified [7].

1. Mixtures of whey (processed or unprocessed, including UF permeates) with fruit or (rarely) vegetable juices;

2. Dairy-type, 'thick' beverages (fermented or unfermented);

3. Thirst-quenching carbonated beverages (the 'Rivella-type'); and

4. Alcoholic beverages (beer, wine or liqueurs).

Some of the commercial formulations are as shown in Table 2.

\section{Whey beverages based on fruit juices}

Mixtures of fruit juices and unprocessed or deproteinated whey or UF permeates are the most common types of whey drinks to be 
manufactured. These products usually fulfill a role similar to typical fruit juices, including breakfast-type beverage, healthful fruit juice snack-type drink, or drinks with a healthful image as a source of vitamins. The main two basic ingredients are typically liquid whey and liquid fruit juice or, more likely, fruit juice concentrate. The flavors used in these beverages most often include citrus fruits (mainly orange, followed by lemon, rarely grapefruit), as well as mango, passion fruit, pear, apple, strawberry, raspberry or fruit juice combinations with exotic descriptive terms ('tropic mix', 'multifruit', 'fruit nectar', etc.) since they have proved to be very efficient in covering up the undesirable odor of cooked milk and salty-sour flavor of fresh whey [8]. The additions of berries which are known as a good source of iron and antioxidants have proved to be very useful. Best example is a whey drink flavoured by addition of strawberry concentrate and fortified with ferrous bisglycinate. Long-term consumption of this drink had an impact on reduction in the prevalence of anemia in children and adolescents [9]. Whey based watermelon beverage was prepared by bending watermelon juice (15\%), sugar $(7 \%)$ and different concentration of Betel leaves distillate $(0,1,2,3 \%)$ into chhanna whey (78$75 \%)$. The prepared beverage has red colour, highly acceptable taste and overall acceptability. The overall acceptability of beverage improved with increase in betel leaves distillate upto $2 \%$. After in-bottle sterilization and cooling, the beverage was stored at refrigerated temperature [10].

Products containing vegetable juices (e.g. carrot) are also available in the market and can be found sporadically in some local markets. A typical production sequence includes blending of the two main liquid ingredients, followed by proper heat treatment and packaging [11]. Defect like development of a sediment due to the insolubilisation of whey proteins upon the heat treatment are reported by many scientists. Webb [11] described the development of a combination cold drink or soup beverage made from tomato juice and sweet whey. The product contained $65 \%$ tomato juice, $34 \%, 6 \%$ fresh sweet whey and whey cream respectively and $0.4 \%$ salt. This mixture had a $\mathrm{pH}$ of 4.3 to 4.5 and contained $2.5 \%$ butterfat. 'Detskii' was made by adding pasteurized sugar syrup and carrot juice to deproteinized whey. The mixture was then pasteurized and bottled. The beverage contained $20 \%$ total solids, and $15 \%$ sugar and the acidity should not be greater than $12.5^{\circ}$ SoxletHenkel.

\section{Dairy-type whey beverages}

In contrast to whey beverages resembling fruit juices, the use of whey or whey components in a drinkable yogurt or a similar dairytype beverage is less straightforward. There are two basic types of dairy beverages:

1. unfermented milk and milk derivatives, milk shakes, flavoured milk and similar products (based on skim, partially skimmed, fullfat or even fat-enriched products); and

11. fermented products such as sour milk, buttermilk, kefir and other similar cultured dairy beverages. The main difference is the $\mathrm{pH}$; which is to the neutral range $(\mathrm{pH} \mathrm{6.2-6.5)} \mathrm{in} \mathrm{the} \mathrm{former,} \mathrm{while}$ most fermented dairy products and acid whey are quite acidic, with the $\mathrm{pH}$ of $4.8-4.5$ [12].

Production of whey beverages with low alcohol content includes deproteinizing whey, whey concentration, fermentation of lactose (usually by yeast strains Kluyveromyces fragilis and Saccharomyces lactis) or addition of sucrose until reaching the desired alcohol content (0.5-1\%), flavoring, sweetening and bottling. Some of noted beverages belonging to this category are 'Milone' obtained by fermentation with kefir culture and whey sparkling wine 'Serwovit' produced in Poland. One of the most famous whey beverages obtained by fermentation with Lactobacillus rhamnosus is 'Gefilus' which is being produced in Finland using demineralized whey or whey protein concentrates with prior lactose hydrolysis which is flavored by addition of fruit juices or fruit aromas and fructose as sweetening agent. There are even some indications that fermentation of whey using yoghurt culture (Lactobacillus delbrueckii sp. bulgaricus and Streptococcus thermophilus) produces a more intense yoghurt flavor compared to the one obtained when skim milk is fermented. In some recent studies whey was fermented by using following strains Lactobaciluus acidophilus, Lactobacillus delbrueckiis sp. bulgaricus, Streptococcus thermophillus, Lactobacillus rhamnosus and Bifidobacterium animalis sp. lactis $[13,14]$.

Vajdi and Pereira [15] described the use of whey as a milk substitute in the production of strawberry, lemon, and chocolate

\begin{tabular}{|c|c|c|c|c|c|c|c|}
\hline \multirow{2}{*}{ Nutrient Ingredient } & \multirow{2}{*}{ Units } & \multicolumn{6}{|c|}{ Value per $\mathbf{1 0 0}$ grams of Edible Protein } \\
\hline & & Dry Sweet Whey & WPC34 & WPC80 & WPC90 & WPI & WPI Hydrolyzed \\
\hline \multicolumn{8}{|l|}{ Proximate } \\
\hline Water & g & 3.19 & 3.93 & 4.11 & 4.00 & 4.50 & 4.50 \\
\hline Energy & kcal & 353.00 & 369.00 & 412.00 & 400.00 & 371.00 & 360.00 \\
\hline Energy & $\mathrm{kj}$ & 1476.00 & 1542.00 & 1722.00 & 1672.00 & 1550.00 & 1504.00 \\
\hline Protein & $\mathrm{g}$ & 12.98 & 34.36 & 80.00 & 80.00 & 90.75 & 90.00 \\
\hline Total Lipid (fat) & g & 1.07 & 3.93 & 6.60 & 6.25 & 0.50 & 0.50 \\
\hline Carbohydrates & g & 74.46 & 50.80 & 5.31 & 6.00 & 0.87 & 0.50 \\
\hline Ash & g & 8.35 & 6.99 & 3.98 & 3.75 & 3.38 & 4.50 \\
\hline \multicolumn{8}{|l|}{ Minerals } \\
\hline Calcium, Ca & $\mathrm{mg}$ & 796.00 & 569.00 & 423.00 & 400.00 & 600.00 & 200.00 \\
\hline Iron, Fe & $\mathrm{mg}$ & 0.88 & 0.89 & 1.20 & & 5.00 & 5.00 \\
\hline Magnesium, Mg & $\mathrm{mg}$ & 176.00 & 104.00 & 50.00 & 50.00 & 15.00 & 10.00 \\
\hline Phosphorous, $\mathrm{P}$ & $\mathrm{mg}$ & 932.00 & 547.00 & 0.00 & 325.00 & 25.00 & 30.00 \\
\hline Potassium, K & $\mathrm{mg}$ & 2080.00 & 1680.00 & 517.00 & & & 800.00 \\
\hline Sodium, $\mathrm{Na}$ & $\mathrm{mg}$ & 1079.00 & 630.00 & 255.00 & 225.00 & 450.00 & 1000.00 \\
\hline Zinc, Zn & $\mathrm{mg}$ & 1.97 & 0.21 & & & & \\
\hline Copper, Cu & $\mathrm{mg}$ & 0.07 & & & & & \\
\hline Manganese, Mn & $\mathrm{mg}$ & 0.009 & 0.06 & & & & \\
\hline Selenium, Se & $\mathrm{mcg}$ & 27.20 & & & & & \\
\hline
\end{tabular}

Table 1: Nutritional composition of whey protein products. 
Citation: Chavan RS, Shraddha RC, Kumar A, Nalawade T (2015) Whey Based Beverage: Its Functionality, Formulations, Health Benefits and Applications. J Food Process Technol 6: 495. doi:10.4172/2157-7110.1000495

Page 4 of 8

\begin{tabular}{|c|c|c|c|c|c|c|c|}
\hline \multirow{2}{*}{ Ingredients } & \multirow{2}{*}{ Isotonic Drink } & \multirow{2}{*}{$\begin{array}{l}\text { Low pH Juice } \\
\text { Drink }\end{array}$} & \multicolumn{3}{|c|}{ Meal Replacement } & \multirow{2}{*}{ Low Sugar Drink } & \multirow{2}{*}{ Juice Drink } \\
\hline & & & Drink & Beverage Mix & Beverage & & \\
\hline Skim Milk & - & - & 93.00 & - & - & - & - \\
\hline Skim Milk powder & - & - & - & 22.45 & - & - & - \\
\hline Cream & - & - & - & - & - & 2.11 & - \\
\hline Creamer & - & - & - & 11.65 & - & - & - \\
\hline Canola Oil & - & - & - & 6.20 & - & - & - \\
\hline Water & 85.43 & 80.73 & - & - & 78.40 & 90.62 & 79.57 \\
\hline Fructose & 9.00 & 9.40 & - & 15.00 & 6.00 & - & - \\
\hline Sugar & - & - & 4.70 & 10.25 & 3.00 & - & 8.33 \\
\hline Sucralose & - & - & - & - & - & 0.10 & - \\
\hline WPI & 5.00 & 4.70 & - & - & - & - & - \\
\hline WPC 80 & - & - & 1.40 & 22.20 & 4.58 & 5.29 & 5.20 \\
\hline Coffee & - & - & - & 4.20 & - & - & - \\
\hline Cocoa Powder & - & - & - & 2.80 & - & - & - \\
\hline Fiber & - & - & - & - & 1.60 & - & - \\
\hline Peach Juice Conc.' & - & - & - & - & - & - & 5.09 \\
\hline Apple juice Conc.' & - & 4.70 & - & - & - & - & - \\
\hline Natural color/flavor & - & - & - & - & 0.30 & - & - \\
\hline Vanilla Extract & - & - & 0.50 & - & - & - & - \\
\hline Natural Mango Flavor & 0.05 & - & - & - & - & 0.20 & - \\
\hline Natural Beery Flavor & - & 0.10 & - & - & - & - & - \\
\hline Natural Flavor & - & - & - & 1.40 & - & - & - \\
\hline Yellow Color & 0.04 & - & - & - & - & 0.01 & - \\
\hline Red Color & - & 0.02 & - & - & - & 0.02 & - \\
\hline Mono and diglycerides & - & - & 0.20 & - & - & - & - \\
\hline Carrageenan & - & - & 0.10 & - & - & - & - \\
\hline Stabilizer & - & - & - & - & 0.60 & - & - \\
\hline Pectin & - & - & - & - & - & 1.37 & 1.30 \\
\hline Guar/Xanthan gum blend & - & - & - & 1.70 & - & - & - \\
\hline Phosphoric acid & 0.37 & 0.35 & - & - & - & 0.28 & 0.20 \\
\hline Citric/phosphoric acid & - & - & - & - & 1.50 & - & - \\
\hline PotassiunSorbate & 0.04 & - & - & - & - & - & - \\
\hline Salt & 0.04 & - & - & - & - & - & - \\
\hline Calcium chloride & 0.02 & - & - & - & - & - & - \\
\hline Milk Calcium & - & - & - & - & - & - & 0.31 \\
\hline Potassium chloride & 0.01 & - & - & - & - & - & - \\
\hline Tetrasodium pyrophosphate & - & - & 0.10 & - & - & - & - \\
\hline Milk Minerals & - & - & - & 1.30 & - & - & - \\
\hline Vitamin/Mineral premix & - & - & - & 0.85 & 0.02 & - & - \\
\hline
\end{tabular}

Table 2: Commercial formulation for whey based beverages.

beverages. The $\mathrm{pH}$ of liquid whey was adjusted to 6.7 with $0.1 \mathrm{~N} \mathrm{KOH}$. Strawberry drink was prepared by adding $2.59 \mathrm{~kg}$ of $35 \%$ fat cream, $2.27 \mathrm{~kg}$ of sugar, $2.72 \mathrm{~kg}$ of skim milk powder, stabilizers, and flavoring to $39 \mathrm{~kg}$ of liquid whey. The mixture was stirred vigorously, heated at $82^{\circ} \mathrm{C}$ for $2 \mathrm{~min}$, and homogenized at 35.2 and $105.5 \mathrm{~kg} / \mathrm{cm}^{2}$. After homogenization the product was cooled to $10^{\circ} \mathrm{C}$ and bottled. Lemon drink was prepared in similar fashion after addition of $2.59 \mathrm{~kg}$ of $35 \%$ fat cream, $2.27 \mathrm{~kg}$ of sugar, flavors, and stabilizers to $40.8 \mathrm{~kg}$ of whey concentrate. Chocolate drink was prepared after addition of $2.27 \mathrm{~kg}$ of sugar, $0.91 \mathrm{~kg}$ of chocolate, $3.63 \mathrm{~kg}$ of whey powder, and stabilizer to $38.6 \mathrm{~kg}$ of liquid whey. These products had low production costs and good flavor.

Cultured dairy beverages based on milk typically contain nondairy ingredients to ensure that the coagulated casein is appropriately stabilized. Suitable for use in fermented whey beverages production are carboxymethyl cellulose, pectin, alginate and xanthan gum since their addition significantly enhances mouth feel of the end product [16]. In this regard, dairy-type whey beverages based on fermentation of liquid whey protein concentrates offers a major opportunity for production of non-sedimenting, 'thin' fermented dairy products. The problem of insolubilised protein sedimentation is much less important in the case of unfermented, market-milk-type dairy beverages. Clearly, for drinkable dairy-based beverages containing liquid WPCs, the sweet whey would be the preferred raw material. Use of dry WPC and WPI products for protein enrichment of milk and milk-based beverages appears feasible [17]. Similarly, although using whey protein materials in yogurts is widespread, much less information is available on yogurt drinks produced by incorporation of whey into the drinkable yogurt $[18,19]$. Big attention has been paid to development of probiotic whey beverages, since beneficiary effects of probiotic strains on human health like lowering cholesterol level in blood, improving lactose metabolism, lowering blood pressure, anticancerogenic properties and immune system stimulation are known for a long period of time [20]. Many 
studies regarding fermentations with probiotic strains Lactobacillus reuteri and Bifidobacterium bifidum have been made whereby Mendoza et al. [21] managed to produce an acceptable probiotic whey beverage with addition of sugar and pectins.

\section{Whey Based Thirst-Quenching Carbonated Beverages}

Now-a-days some authors have suggested the addition of $\mathrm{CO}$ combined with fruit added in it to overcome the undesirable flavor and odor of cooked milk [22]. The most typical product representing this type of whey beverage is the Swiss 'Rivella'.

Rivella, a sparkling, crystal clear infusion of alpine herbs, first, appeared in Switzerland in 1952 [23]. Rivella was prepared by fermenting deproteinized whey with lactic acid bacteria, filtering, condensing to a 7:1 concentrate, adding sugar and flavoring, refiltering, diluting and carbonating, after which the product was bottled and pasteurized. The finished beverage contained $9.7 \%$ total solids, $0.125 \%$ total nitrogen and the $\mathrm{pH}$ was about 3.7 [24]. Other beverages that have received attention include Bodrost, an alcoholic beer-like beverage made in Russia from pasteurized, clarified whey with the addition of sugar and raisins [25]. Tai from Brazil is a soft drink fortified with a whey protein concentrate to contain $1.5 \%$ protein [26]. Other whey beverages (from deproteinized whey) sold in Europe includes Big MR, Frusighurt (Germany) and Taksi' (Holland) [27].

The product is an archetype of a thirst-quenching, carbonated drink, resembling the most typical 'pop-type beverages' with the main ingredient being water. Since the liquid whey component is highly clarified, containing no whey protein, the carbonation of the product is not complicated by the strong foaming characteristic of the whey protein. This is a major disadvantage of the traditional whey-based beverages and an advantage for a product whose main role is thirstquenching rather than enhanced nutrition. However, one of the latest variants of the Rivella, the 'Rivella-green' has been developed using herbal extracts from green tea as a move towards enhanced nutritional benefits. A similar product was developed by the Swiss food retailing giant Migros.

The citrus flavored beverages particularly orange, have received the highest acceptability. The orange-flavored drink contained 33\% untreated cottage cheese whey. Citric acid was added to $\mathrm{pH} 3.6$ to overcome the buffering capacity of the whey. When using fruits, it is recommended that natural fruits be well ripened. Various fruits including peach puree $(20 \%)$, strawberry $(10 \%)$ and red raspberry $(10 \%)$ have been used successfully at these levels.

Lactofruit, a whey drink developed in Switzerland was made by hydrolyzing deproteinized whey to $50 \%$ with lactase to increase sweetness and avoid lactose intolerance. The beverage contained $25 \mathrm{~g} / \mathrm{l}$ galactose, $4.5 \mathrm{~g} / \mathrm{l}$ minerals, $2 \mathrm{~g}$ nitrogenous substances, $\mathrm{B}$ vitamins and vitamin C. Jelen [7] reported that the lack of high marketability for whey beverages, when compared to other beverages, was due to poor flavor blends. Whey contains high amounts of lactose and salts which makes it a difficult material to utilize. Various flavor notes including diacetyl, acid, saltiness, astringency, bitterness and sweetness have been reported [28]. Engel [29], patented a process for producing a sherrylike alcoholic beverage from whey in which fresh whey and sucrose in the proportions of 2.5:1 up to 9:1 were fermented with 1.2 to $9.9 \%$ baker's yeast followed by aging for 3.5 months. The liquid was then siphoned from the tank and stored in the dark for 10 to 54 days to permit flavor development. After chilling to $-23^{\circ} \mathrm{C}$ for 4 days to fix the flavor, it was aged at $10^{\circ} \mathrm{C}$ for several days, at which time it was ready for use as a flavoring agent or a beverage.
A dietetic whey beverage was prepared by Blazek and Sule [30] in which the whey was first inoculated with a 2 to $5 \%$ culture such as Streptococcus lactis, Streptococcus diacetilactis, Saccharomyces fragilis or Torulopsis sphaerica, either singly or in combination, and incubated at 15 to $25^{\circ} \mathrm{C}$ to $\mathrm{pH} 4.4$ to 4.6 . After addition of ethanol, the mixture was boiled to coagulate the proteins and filtered. The $\mathrm{pH}$ of the filtrate was adjusted to 5, and flavorings such as sultanas or apples and citric acid and vitamins were added. The beverage was then diluted, reclarified, pasteurized, the $\mathrm{pH}$ readjusted to 5, carbonated, and bottled.

Carbonation is one of the critical aspects for success of the thirst quenching whey beverages. This seemingly simple technological step is, in reality, quite complex and extremely difficult to accomplish with regular dairy whey containing the highly foamable whey proteins.

\section{Other Beverages Based on Whey and Whey Components}

Dietetic beverages, beverages with hydrolyzed lactose, are prepared by addition of some sweetening agent (most often saccharin and cyclamate), fruit bases of apple or some tropical fruits and stabilizing agent. These beverages have very low energy value $(104-113 \mathrm{~kJ} / 100$ $\mathrm{ml}$ ) what makes them suitable for consumption by large group of consumers. Lactose hydrolyzation results in production of glucose and galactose - monosaccharides with much higher sweetness, better solubility and better absorption ability than lactose.

Besides fruits, other flavoring agents like chocolate, cocoa, vanilla, cereals (mostly rice, oat and barley), honey, etc are added. Addition of cereals (especially bran), seems to be very interesting which results in production of a beverage fortified with dietary fibers, essential fatty acids (with addition of oat) and hypoallergenic proteins what makes these beverages suitable for consumption by allergic population and children. In order to prepare a hypoallergenic beverage, the addition of other vegetable sources of proteins like isolates of potato or soy proteins may be used. Addition of honey to such beverage instead of sugar or other sweeteners results in fortifying it with numerous other nutrients like vitamins, minerals and pytochemicals which are not naturally present in whey.

Drgalic et al. [31] studied survival and growth of probiotic strains Lactobacillus acidophilus La-5, Bifidobacterium bifidum Bb-12 and Lactobacillus casei Lc- 1 in reconstituted whey for 28 days of cool storage. Therefore choice of the proper type and level of hydrocolloid used is one of the most important factors in the manufacture of fermented dairy products. In fact, it is very important that added hydrocolloids do not mask natural flavor of the product and that they are effective at the typical product $\mathrm{pH}$ range i.e. 4.0-4.6.

\section{Whey Fruit Beverages Based on Paneer Whey}

Paneer whey was added with guava pulp to produce a soft beverage by adding guava pulp (25\%), sugar (10\%) and paneer whey $(65 \%)$ and whey-guava beverages pasteurized at $70^{\circ} \mathrm{C}$ for $35 \mathrm{~min}$ showed the maximum acceptability after 45 days of storage on sensory tests. Effect of different temperatures, timings and storage periods on the mean sensory sources of whey-guava beverage was significant [32]. The beverage contained whey (65\%), sugar (10\%), guava pulp $(25 \%)$, guar gum $(0.05 \%), \mathrm{SO}_{2}$ (including potassium Meta bisulphite $100 \mathrm{ppm}$ ) (1.5\%), sodium alginate (1\%). A highly acceptable whey based wheymango concentrate was prepared by using, mango pulp of $25^{\circ} \mathrm{C}$ Brix, paneer whey concentrate of $37 \%$ total solids and sugar were added at the rate of $15 \%, 37 \%$ and $8 \%$ respectively and the final $\mathrm{pH}$ of the product was adjusted to 4.2 . 


\section{Sports drinks}

Sports drinks are the beverages which may contain carbohydrates, minerals, electrolytes, flavoring, and coloring agents. Sports drinks are generally formulated so that their consumption provides to minimize dehydration and to supply carbohydrates and electrolytes for fluid absorption and energy, they also aid in fluid retention, and enhance flavor. Rehydration effectiveness of sports drinks is normally assessed by the indices of gastric emptying, intestinal absorption, and fluid retention. Retaining fluid is crucial for optimal physiological function, improved performance, and rapid recovery, especially if multiple bouts of exercise are required [33,34]. As compared to traditional sports beverages, inclusion of small amounts of protein (typically $20 \%$ of total calories) in a beverage may produce benefits and may increase performance time to fatigue, reduce post exercise muscle damage, and enhance muscle glycogen repletion [35]. Most of the mainstream commercial sports drinks have a rather similar formulation, suggesting some consensus among the manufacturers as to the key components of an effective sports drink (Table 3).

In general, these drinks are approximately isotonic, with an osmolality that is typically between about 280 and $340 \mathrm{mosmol} / \mathrm{kg}$. The carbohydrate content is usually about $6-7 \%$ and usually includes some combination of glucose, fructose, sucrose and maltodextrin. The sodium concentration is typically in the range of about $20-30 \mathrm{mmol} / \mathrm{l}$ and the potassium is about $5 \mathrm{mmol} / \mathrm{l}$. Table 4 illustrates the composition of selected sports drinks and common beverages [36].

A well designed sports drinks is consumed by the sports person with different perceptions like, consumption of sport drink will encourage more consumption of fluid, it can stimulate rapid absorption of fluid, a good source for supply of instant carbohydrates which may increase the performance, its consumption may encourage physiologic response, it can be a source of fast and easy rehydration.

The physiological and performance responses of an athlete can be altered by making minor changes in the formulation of sports drinks and can be achieved by adjusting the ratio of carbohydrates, proteins and sodium [37]. Table 5 depicts the formulations of sports drink.

Health benefits of milk are well established and is looked upon as a better alternative for manufacturing of sports drinks. New research shows that milk consumed as a post-exercise recovery and rehydration beverage is just as effective, if not more so, than commercially-available sports drinks, and can increase muscle growth [38]. The generally recommedned protein intake for the athletes is about $1 \mathrm{~g}$ (general training) and $2 \mathrm{~g}$ (intense training loads, adolescents in a growth spurt, muscle building) of protein/ $\mathrm{kg}$ bodyweight per day. Many athletes consume whey protein for its rich branched chain amino acid (BCAA) content. Because the demand for BCAAs increases with endurance exercise, whey protein is an ideal way to replace these BCAAs to enhance protein synthesis and muscle growth during the recovery period. Whey proteins are particularly effective at stimulating muscle protein synthesis rates because the AA profile in whey is almost identical to that of skeletal muscle [39]. In addition, the relatively high levels of EAAs in whey proteins are effective at stimulating protein synthesis in adult muscle (Table 5).

Recent studies suggest that whey proteins can help improve lean body mass and performance in athletes on a resistance training regimen. Lands et al. [40] obsereved a improved volitional performance (peak power and $30 \mathrm{sec}$ work capacity) compared with a casein placebo in the atlethes who were given supplements of a "whey-based cysteine donor", at the rate of $20 \mathrm{~g}$ day for three months. The supplement was designed to augment anti-oxidant defences by increasing intracellular glutathione (GSH) and thereby reduce muscular fatigue.

\section{Conclusion}

In the present fiercely competitive beverage market, the classical whey drinks may be facing tough times. For a beverage to be accepted by the modern consumers, it has to satisfy at least some of the main determinants of success-desirable sensory quality, thirst-quenching effectiveness, favorable price and positive 'health image'. With the peculiarities of the whey flavor interfering with many flavoring ingredients and the processing costs adding to the rapidly rising value of the formerly bothersome waste, the future of the whey beverages might lie mainly in the last attribute, the special nutraceutical qualities of some of the whey components. Consumer features like convenience, practicability, flavor, nutritional value, variants are generally affecting the market size of the functional drinks. As far as milk is concerned, it is now steadily becoming a functional drink in its various forms like drinkable yoghurt, flavored milk and others and a vital role will be played by whey based drinks. Whey drinks with added carbohydrates and increased level of salts can be used for formulating sports drinks

\begin{tabular}{|c|c|c|c|c|}
\hline Beverage & Carbohydrate (\%) & Sodium (mmol/l) & Potassium (mmol/l) & Osmolality (mosmol/kg) \\
\hline Gatorade $^{\circledR}$ & 6 & 20 & 3 & 310 \\
\hline Isostar ${ }^{\circledR}$ & 7 & 30 & 5 & 290 \\
\hline Lucozade Sport ${ }^{\circledR}$ & 6.4 & 22 & 3 & 285 \\
\hline Powerade ${ }^{\circledR}$ & 6 & 23 & 2 & $280 / 290$ \\
\hline \multicolumn{5}{|l|}{ Fruit Juice } \\
\hline Orange & 10 & 4 & 45 & 660 \\
\hline Apple & 13 & 1 & 26 & - \\
\hline Tomato & 3 & 140 & 7 & - \\
\hline Cola $^{\circledR}$ & 11 & 3 & 1 & 700 \\
\hline
\end{tabular}

Table 3: Composition of selected commercial sports drinks.

\begin{tabular}{|l|l|l|l|}
\hline Beverage & Manufacturing Company & Sodium (mmol/l) & Potassium (mmol/l) \\
\hline AllSport $^{\circledR}$ & Pepsico & 10 & 5 \\
\hline Gatorade $^{\circledR}$ & Quaker Oats Co. & 20 & 3 \\
\hline Powerade $^{\circledR}$ & Coco-Cola & 5 & $8-9$ \\
\hline Whey permeate based sports drink & & 20 & 3 \\
\hline
\end{tabular}

Table 4: Sodium, potassium, and carbohydrate concentration of some commercial and whey permeate experimental beverages. 
Citation: Chavan RS, Shraddha RC, Kumar A, Nalawade T (2015) Whey Based Beverage: Its Functionality, Formulations, Health Benefits and Applications. J Food Process Technol 6: 495. doi:10.4172/2157-7110.1000495

Page 7 of 8

\begin{tabular}{|c|c|c|}
\hline Ingredients & Usage level (\%) & Usage level (\%) \\
\hline Water & - & 77.40 \\
\hline Fructose & 76.64 & 6.00 \\
\hline WPI & 20.00 & - \\
\hline WPC-80 & - & 3.90 \\
\hline Maltodextrin & - & 11.00 \\
\hline Lemon/lime Flavor & 1.10 & - \\
\hline Citric acid anhydrous & 0.65 & 1.00 \\
\hline Sodium chloride & 0.50 & - \\
\hline Sodium citrate & 0.50 & 0.06 \\
\hline Mono potassium Phosphate & 0.40 & - \\
\hline Sodium benzoate & 0.10 & - \\
\hline Flavor color & - & 0.64 \\
\hline Blue color & 0.06 & - \\
\hline Yellow color & 0.04 & - \\
\hline Antifoam agent & 0.01 & - \\
\hline Total & 100.00 & 100.00 \\
\hline Procedure & $\begin{array}{l}\text { Blend all dry ingredients well. Disperse } 18 \% \text { of dry blend into } 82 \% \\
\text { water, stirring until fully hydrated. Using phosphoric acid }(25 \% \\
\text { solution) adjust } \mathrm{pH} \text { to } 2.85-3.0 \text {. Cold-fill bottles and pasteurize to } \\
88^{\circ} \mathrm{C} \text {. }\end{array}$ & $\begin{array}{l}\text { Add water to a batch mixing tank at } 15^{\circ} \mathrm{C} \text { to } 25^{\circ} \mathrm{C} \text {. With good agitation, } \\
\text { add WPC- } 80 \text {, hydrate for } 15-30 \text { min. Mix in fructose, maltodextrin } \\
\text { and sodium citrate with good agitation. Add flavor and color, hydrate } \\
\text { for } 10 \text { min. Adjust to } \mathrm{pH} 3.5 \text { using a } 50 \% \text { acid solution with continuous } \\
\text { mixing. Heat it to } 80^{\circ} \mathrm{C}-85^{\circ} \mathrm{C} \text { for } 15-30 \mathrm{~s} \text {. Hot-fill the containers } \\
\text { followed by immediate cooling. }\end{array}$ \\
\hline
\end{tabular}

Table 5: Formulations of sports drink.

which will be having different function like recovery of muscle and muscle cramps, increase in lean weight, overcoming the adenine nucleotides depletion, acting as a neurostimulant, Glycogen depletion and others. Whey and whey based products can be used to formulate different beverages with multiple application and functionalities.

\section{References}

1. Miller GD (2009) Research leads the whey. Prepared foods

2. Gottschalk $L$ (2005) Winning wheys in bars and beverages. Prepared Foods 175: 71-72.

3. Datamonitor (2006) Global Functional Beverages. London: Datamonitor. Europe.

4. (2009) Mintel International Group, Ltd. Functional Beverages, USA

5. Mulvihill DM (1992) Production, functional properties and stylization of milk protein products. Elsevier Science Publishers LTD. New York, USA.

6. USDEC (2003) Reference manual for U.S. whey and lactose products.

7. Jelen $P$ (1992) Whey cheeses and beverages. Whey and Lactose Processing, London 157-193.

8. Duric M, Caric M, Milanovic S, Tekic M, Panic M (2004) Development of whey based beverages. European Food Research and Technology 219: 321-328.

9. Miglioranza LSH, Matsuo T, Caballero-Cordoba GM, Dichi JB, Cyrino ES, et al. (2003) Effect of long-term fortification of whey drink with ferrous bisglycinate on anemia prevalence in children and adolescents from deprived areas in Londrina, Parana, Brazil. Nutrition 19: 419-421.

10. Naik YK, Khare A, Choudhary PL, Goel BK, Shrivastava A (2009) Studies on physico-chemical and sensory characteristics of whey based watermelon beverage. Asian J. Research Chem 2: 57-59.

11. Webb BH (1938) Utilization of whey in foods. J Food Science 3: 233-281.

12. Athanasiadis A, Paraskeropoulou A, Blekas G, Kiosseoglou V (2004) Development of a novel whey beverage by fermentation with kefir granules effect of various treatments. Biotechnology Progress 20:1091-1095.

13. Almeida KE, Tamime AY, Oliveira MN (2008) Acidification rates of probiotic bacteria in Minas frescalsheese whey, LWT Food Science and Technology 41 311-316.

14. Pescuma M, Hebert EM, Mozzi F, Valdez GF (2008) Whey fermentation by thermophilic acid bacteria: Evolution of carbohydrates and protein content.
Food Microbiology 25: 442-451.

15. Vajdi M, Pereira RR (1973) The feasibility of whey utilization for the production of various drinks. Dairy 52: 14-16.

16. Gallardo-Escamilla FJ, Kelly AL, Delahunty CM (2007) Mouth feel and flavor of fermented whey with added hydrocolloids. J of Dairy Sci 17: 308-315.

17. Peter S, Rattray W, Jelen P (1996) Heat stability and sensory quality of protein standardized $2 \%$ fat milk. Milchwissenschaft 51: 611-616.

18. Burton-Trapp HM (1991) The technological approaches in the developments of a whey-based yogurt beverage. University of Alberta, Edmonton, Canada.

19. Johnson MA, Jelen P, Mitchell IR, Regester GO, Smithers GW (1996) High protein whey drinks. Food Australia 48:360-361.

20. Shah NP (2007) Functional cultures and health benefits. Intern Dairy J 17 1262-1277.

21. Mendoza AH, Robles VJ, Angulo JO, Cruz JDL, Garcia HS (2007) Preparation of a whey-based probiotic product with Lactobacillus reuteri and Bifidobacterium bifidum. Food Technol Biotechnol 45: 27-31.

22. Sherwood S, Jenkins D (2007) US Patent US 2007/0178214.

23. Anonymous (1960) "Rivella"- a new form of whey utilization. Dairy Industries 25: 113-117.

24. Barth R (2001) The importance of whey and whey components in food and nutrition. Proceedings of the 3rd International Whey Conference, Hamburg, Germany.

25. Len'kov NT (1969) Beverage “Bodrost”. Moloch Prom 30: 25-28.

26. (1973) Tomorrow's pop bottles may be loaded with protein. Inck Week 177:42.

27. Lang F, Lang A (1969) More advances in the manufacture of new milk-based food products. Milk Industry 64: 64-69.

28. McGugan WA, Larmond E, Emmons DB (1979) Some observations on the flavor of acid whey. $\mathrm{J}$ of the Canadian Institute of Food Science and Tech 12 32-35

29. Engel ER (1948) Fermenting whey. U.S. patent. Chem. Abstr. 42:9072.

30. Blazek Z, Sule J (1961) Method for the manufacture of dietetic whey beverage. Czech Patent. Dairy Sci Abstr 26: 390.

31. Drgalic I, Tratnik LJ, Bozanic R (2005) Growth and survival of probiotic bacteria in reconstituted whey. Lait 85:171-179.

32. Divya, Kumari A (2009) Effect of different temperatures, timings and storage 
Citation: Chavan RS, Shraddha RC, Kumar A, Nalawade T (2015) Whey Based Beverage: Its Functionality, Formulations, Health Benefits and Applications. J Food Process Technol 6: 495. doi:10.4172/2157-7110.1000495

Page 8 of 8

periods on the physico-chemical and nutritional characteristics of whey-guava beverage. World Journal of Dairy and Food Sciences 4:118-122.

33. (2011) Sports drinks and energy drinks for children and adolescents: Are they appropriate? Committee on Nutrition and the Council on Sports Medicine and Fitness. Pediatrics 127: 1182-1189.

34. Seifert J, Harmon J, De Clercq P (2006) Protein added to a sports drink improves fluid retention. International Journal of Sport Nutrition and Exercise Metabolism 16: 420-429.

35. Saunders MJ, Kane MD, Todd MK (2004) Effects of a carbohydrate-protein beverage on cycling endurance and muscle damage. Medicine and Science in Sports and Exercise 36: 1233-1238.
36. Maughan RJ, Murray R (2001) Sports drinks, basic science and practical aspects. CRC Press LLC, USA.

37. Roy BD (2008) Milk: The new sports drink? A Review. JISSN 2: 5-15.

38. Wolfe RR (2000) Protein supplements and exercise. The American Journal of Clinical Nutrition 72: 551-557.

39. Volpi E, Kobayashi H, Sheffield-Moore M, Mittendorfer B, Wolfe RR (2003) Essential amino acids are primarily responsible for the amino acid stimulation of muscle protein anabolism in healthy elderly adults. The American Journal of Clinical Nutrition 78: 250-258.

40. Lands LC, Grey VL, Smountas AA (1999) Effect of supplementation with cysteine donor on muscular performance. Journal of Applied Physiology 87: 1381-1385. 